$$
\begin{aligned}
& \text { Mulroy, Wi Ji } \\
& \text { Div-745 Ext-5878 } \\
& \text { pages } 26
\end{aligned}
$$

NBSIR 86-3465

\title{
Evaluation of A Standard Device for Calibrating Calorimeter Test Rooms
}

William J. Mulroy

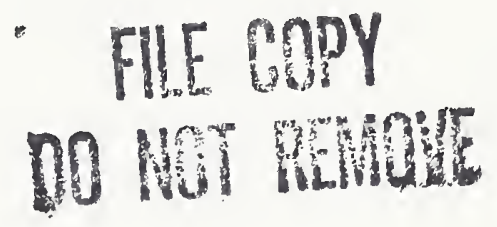

U.S. DEPARTMENT OF COMMERCE

National Bureau of Standards

National Engineering Laboratory

Center for Building Technology

Building Equipment Division

Gaithersburg, MD 20899

December 1986

Sponsored by: 

NBSIR $86-3465$

\section{EVALUATION OF A STANDARD DEVICE FOR CALIBRATING CALORIMETER TEST ROOMS}

William J. Mulroy

U.S. DEPARTMENT OF COMMERCE National Bureau of Standards National Engineering Laboratory Center for Building Technology Building Equipment Division Gaithersburg, MD 20899

December 1986

Sponsored by:

U.S. Department of Energy Washington, DC 20585

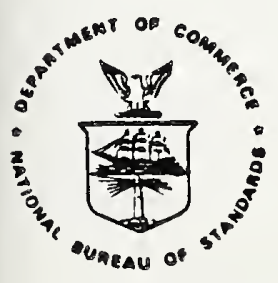

U.S. DEPARTMENT OF COMMERCE, Malcolm Baldrige, Secretary NATIONAL BUREAU OF STANDARDS. Emest Ambler, Director 



\section{Abstract}

A device for calibrating calorimeter test rooms was evaluated by installing it on a test room calorimeter of small, known thermal transmittance which contained electric heaters capable of providing varying metered heat loads. The calibration device was evaluated only for its ability to measure heat load. The calorimeter instrumentation is described in detail. The calibration device is described primarily by reference.

Rey Words: Air conditioning; calorimeters; room air conditioners; test methods; test rooms 


\section{Acknowledgment}

The author wishes to thank the office of Conservation and Renewable Energy of the U.S. Department of Energy for funding National Bureau of Standards (NBS) work on this project and the American Society of Heating, Refrigerating and Air Conditioning Engineers Technical Comittee 7.5 (Room Air Conditioners and Dehumidifiers) for funding Kansas State University (KSU) work on this project under research project 344-RP, "A Standard Device for Calibrating Calorimeter Test Roomso"

The author also acknowledges the efforts of David Ward and Daniel Gaggioli of NBS in instrumenting the NBS calorimeter and in operating the NBS calorimeter and test room and the etforts of Byron Jones and Donald Marvin of KSU in setting up and operating the KSU calorimeter calibration device during the tests described in this report. 


\section{Table of Contents}

$\frac{\text { Page }}{i j i}$

Acknowledgments $\ldots \ldots \ldots \ldots \ldots \ldots \ldots \ldots \ldots \ldots \ldots \ldots \ldots \ldots \ldots \ldots \ldots \ldots \ldots \ldots$

List of Tables $\ldots \ldots \ldots \ldots \ldots \ldots \ldots \ldots \ldots \ldots \ldots \ldots \ldots \ldots \ldots \ldots \ldots \ldots \ldots \ldots$

List of Figures $\ldots \ldots \ldots \ldots \ldots \ldots \ldots \ldots \ldots \ldots \ldots \ldots \ldots \ldots \ldots \ldots \ldots \ldots \ldots \ldots$

1. Introduction $\ldots \ldots \ldots \ldots \ldots \ldots \ldots \ldots \ldots \ldots \ldots \ldots \ldots \ldots \ldots \ldots \ldots \ldots$

2. Description of Calorimeter Calibration Device ............... 2

3. Description of Calorimeter and Instrumentation .............. 5

4. Thermal Transmittance and Air Leakage Tests of

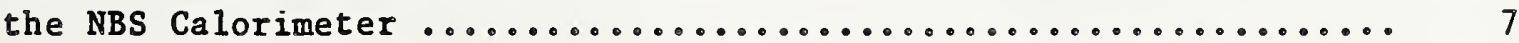

5. Watt Hour Meter Calibrations and Line Loss ................ 10

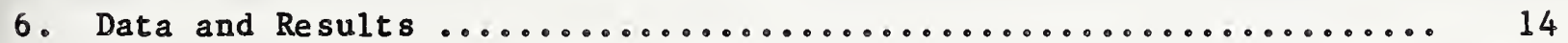

7. Discussion and Conclusions .......................... 17

8. References ....................................... 18 


\section{List of Tables}

Table 1. Thermal Transmittance Tests of Calorimeter.............

Table 2. Calorimeter Air Leakage Test Results .................. 8

Table 3. Test Watthour Meter Calibrations .................... 10

Table 4. Summarized Calorimeter Heat Gain Data ................ 14

Table 5. Comparison of Calorimeter Heat Gain as

Measured by NBS and KSU ............................ 14

Table 6. Summarized Calorimeter Humidity and

Condensate Data ............................ 15

\section{List of Figures}

Figure 1. Schematic Diagram of KSU Calorimeter

Calibration Device Enthalpy Loop .................... 4

Figure 2. Air Leakage Test s of Calorimeter .................... 9

Figure 3. Base Heat Circuit Line Loss ....................... 12

Figure 4 . 110 Volt Circuit Line Loss ...................... 13

Figure 5. Comparison of Calorimeter Heat Gain

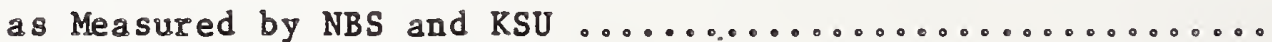




\section{Introduction}

The objective of this project was to evaluate a device for calibration of room air conditioner calorimeters (calorimeter test rooms) as described in [1]. Evaluation was 1 imited to determination of whether the calibration device had met its design goal of measuring its cooling capacity with an accuracy of $\pm_{1 / 2 \%}$.

This evaluation was performed by installing the calorimeter calibration device on a calorimeter of small, known thermal transmittance and providing metered electric resistance heat within the calorimeter to match cooling capacities of several different levels provided by the calibration device.

Because of time limitations, tests were run only at five points ranging from 8250 $\mathrm{Btu} / \mathrm{hr}(2.42 \mathrm{~kW})$ to $29,000 \mathrm{Btu} / \mathrm{hr}(8.50 \mathrm{~kW})$ which were selected by Kansas State University (KSU), the builders of the tested calibration device, to be representative of the design operating range of $4000 \mathrm{Btu} / \mathrm{hr}(1.17 \mathrm{~kW})$ to $34,000(9.96 \mathrm{~kW}) \mathrm{Btu} / \mathrm{hr}$. Humidity was supplied within the calorimeter (nominal $80^{\circ} \mathrm{F}\left(26.7^{\circ} \mathrm{C}\right)$ dry bulb, $67^{\circ} \mathrm{F}\left(19.4^{\circ} \mathrm{C}\right)$ wet bulb) for the first three tests. The last two tests were performed without humidity addition.

The calorimeter instrumentation, operation, data recording and data reduction were performed by National Bureau of Standards (NBS) personnel. Installation on the calorimeter, operation, data recording and data reduction for the calibration device were performed by KSU personnel. 


\section{Description of Calorimeter Calibration Device}

The calorimeter calibration device is described in detail in [3], [4], [5] and [6]. A sketch of the device is shown in figure 1. Brief ly, the device functions by circulating refrigerated brine through two parallel circuits, one which cools the calorimeter being calibrated and the other which passes over metered electric resistance heaters. The power of the metered electric heaters is controlled so that when the two parallel circuits join they are at the same temperature. The flow rate in each of the parallel circuits is measured by piston type volumetric flow meters. The net cooling done by the coil in the calorimeter is calculated as:

$$
\dot{Q}=P_{h} \frac{\grave{V}}{\dot{V}_{h}}-P_{f}
$$

where:

$\oint=$ Net cooling performed by coil in the calorimeter, $W$

$P_{f}=$ Air circulating fan power within the calorimeter, $W$

$P_{h}=$ Power to the electric resistance heaters in the comparison circuit, $W$

$\dot{V}=$ Volumetric flow rate of brine through the cooling coil in the calorimeter, $\mathrm{m}^{3} / \mathrm{s}$

$\dot{V}_{h}=$ Volumetric flow rate of brine through the comparison electric resistance heater circuit, $\mathrm{m}^{3} / \mathrm{s}$.

Latent capacity was measured by condensate collection.

No secondary cest method was employed as a check on the primary test method measurement of either total, sensible, or latent capacity. A "check" circuit 
is provided which al lows the passing of the cooling brine over a metered electric resistance heater instead of through the calorimeter cooling heat exchanger.

The heat flow meter secondary test method described in [5] was not used during these tests. 


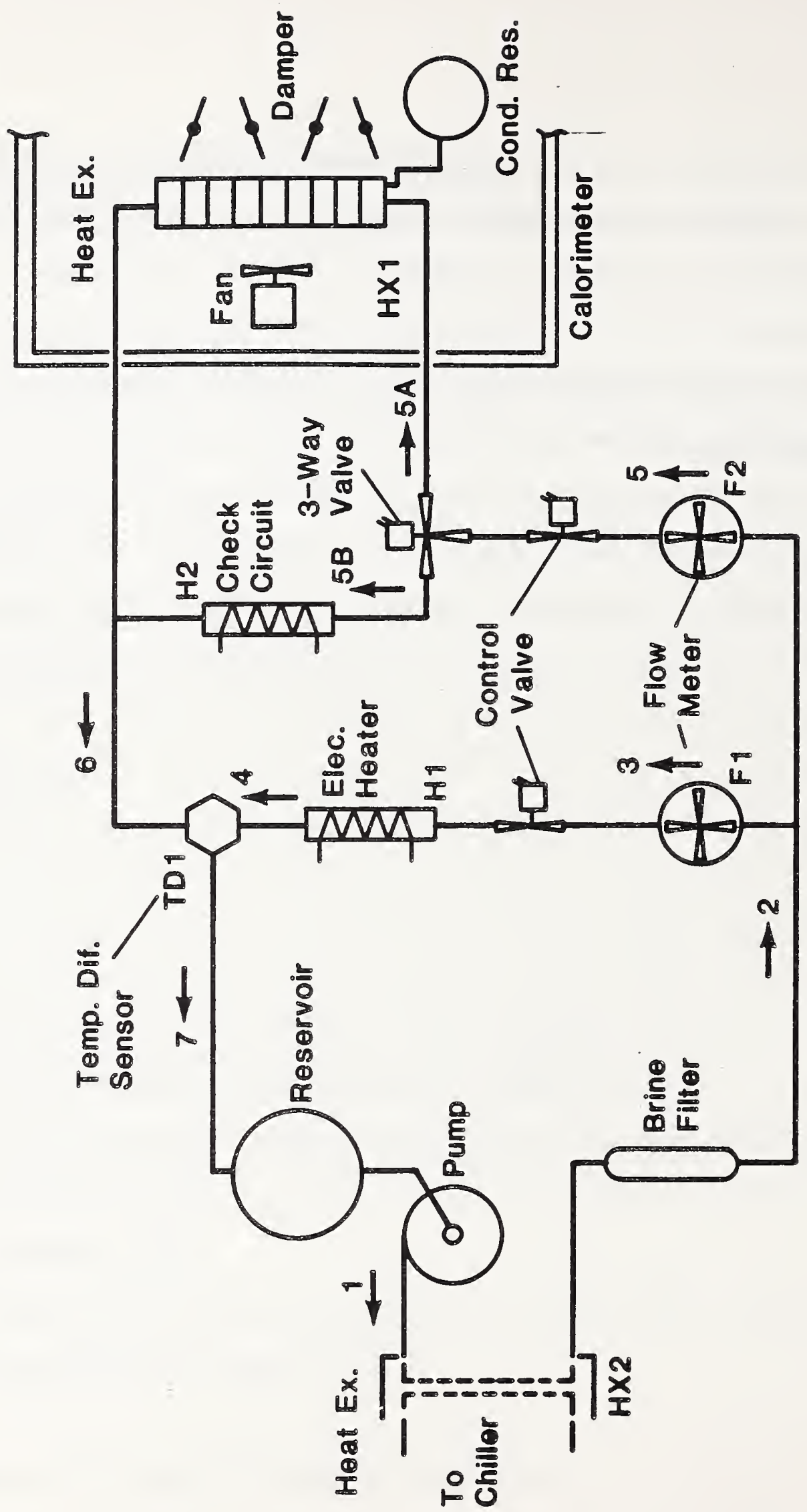

Bigure 1: Schematic Diagram of RSU Calorimeter Calibration Device Enthalpy Loop (Nomenclature Pertains to Reference 6) 


\section{Description of Calorimeter and Instrumentation}

The insulated box used as a calorimeter for these tests had previously been received at NBS for use in another project and was a nominal 10 foot (3 m) intermodal thermal van container [7] designed for transporting frozen food. The walls of the calorimeter were insulated with 4 inches $(100 \mathrm{~mm})$ of foamedin-place polyurethane insulation. The interior dimensions were 87 inches $(2.2$ m) wide by 81 inches $(2.1 \mathrm{~m})$ high by 89 inches $(2.3 \mathrm{~m})$ deep. The calorimeter was installed in an environmental test chamber capable of separately controlling the surrounding ambient temperature and humidity. The calorimeter was supported on four 11-3/8 inch (290 mm) blocks placed at each corner to al low air circulation beneath it. The calorimeter was instrumented with thermocouples located at each internal corner, 6 inches $(150 \mathrm{~mm})$ from each intersecting wal $l$ and at each external corner 8 inches (200 mm) distant from the corner. An insulated plug was installed in the opening intended for a refrigeration unit. All wires and pipes needed for these tests were run through this plug.

Electric heaters were instal led in the calorimeter to provide varying degrees of load to the calorimeter calibration device. These heaters were divided into base heaters on one watt hour meter in steps of $1.5 \mathrm{~kW}, 3 \mathrm{~kW}$ and $4 \mathrm{~kW}$ and a variable heater of $1.3 \mathrm{~kW}$ on a separate watt hour meter. Power was supplied to the variable heater by a silicon control led rectifier (SCR) circuit controlled by a single pen recorder/controller capable of being set to provide either a fixed heat input to the calorimeter or to automatically vary the heat input to obtain a set temperature. The SCR power controller was designed to drop out complete alternating current cycles by switching at zero voltage to minimize radio interference and maintain a sine wave shape to the power cycles 
so as to al low accurate power measurement with conventional instruments.

Humidifiers were placed inside the calorimeter to provide a latent load for some tests of the calorimeter calibration device. They were mounted on load cells to provide measurement of theix water evaporation rate. The humidifiers held sufficient water to eliminate the need for refilling during a test.

Energy to the humidifiers, a circulating fan, and a motorized psychrometer was measured by a 110 volt watthour meter. Enexgy measurements were converted to powers by division by the test duration before reporting in the tables and figures of this report. 


\section{Thermal Transmittance and Air Leakage Tests of the NBS Calorimeter}

The tests described in this section are calibration tests of the NBS calorimeter, not tests of the KSU calorimeter calibration device.

The thermal transmittance test was performed using the reverse heat loss method in which the calorimeter interior temperature is raised above the laboratory ambient temperature by automatically controlled, metered, electric resistance heaters. Thermal conditions were allowed to stablize for 24 hours prior to a 23 hour data collection period. The test data and results are summarized in Table 1.

\section{Table 1}

Thermal Transmittance Tests of Calorimeter

$\begin{array}{lll}\text { Average Interior Temp, },{ }^{\circ} \mathrm{F}\left({ }^{\circ} \mathrm{C}\right) & 104.6 & (40.3) \\ \text { Average Ambient Temp., }{ }^{\circ} \mathrm{F}\left({ }^{\circ} \mathrm{C}\right) & 36.4 & (2.4) \\ \text { Thermal Transmittance, Btu/hr }{ }^{\circ} \mathrm{F}(\mathrm{W} / \mathrm{K}) & 29.71 & (15.67) \\ \text { Temperature Differential, }{ }^{\circ} \mathrm{F}(\mathrm{K}) & 68.2 & (37.9) \\ \text { Mean Wall Temperature, }{ }^{\circ} \mathrm{F}\left({ }^{\circ} \mathrm{C}\right) & 70.5 & (21.4)\end{array}$

This measured thermal transmittance is $28 \%$ greater than that measured 10 years previously at NBS when the calorimeter was new. This level of degradation is high, but not unreasonable, for foamed-in-place polyurethane [2].

The calorimeter isothermal air leakage was measured at three pressure differentials. For these tests the calorımeter interior was pressurized using the NBS laboratory compressed air supply. Air flow rate measurements were made using a 10 cubic foot $\left(0.283 \mathrm{~m}^{3}\right)$ per revolution dry gas meter in series in the air supply. The interior-exterior pressure differential was measured using a micromanometer. All reported tests were performed with the calorimeter door taped to reduce the leakage around the door gasket. The test results are 
listed in Table 2 and plotted for comparison to previous tests in figure 2. Table 2

Calorimeter Air Leakage Test Results

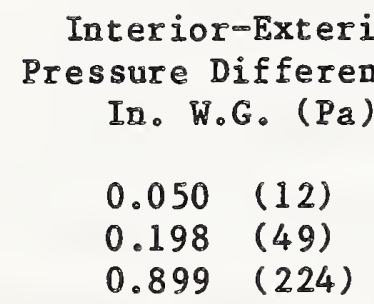

Air Leakage Rate, $\operatorname{SCFM}(\ell / 3)$

$\begin{array}{ll}0.80 & (0.38) \\ 2.29 & (1.08) \\ 6.83 & (3.22)\end{array}$

$6.83(3.22)$

The air leakage can be seen in figure 1 to be unchanged from its original value measured at NBS shortly after manufacture of the calorimeter.

The measured thermal transmittance value was used in data analysis of the KSU calorimeter calibration device without any adjustment for alr leakage or mean wall temperature. No adjustment for air leakage could be made since the calorimeter calibration device tests were conducted at nearly isothermal conditions causing any aix leakage to be a result of internal fan placement or of humidity gradient, neither of which al low easy quantitative estimation of infiltration. The air leakage tests do make possible the qualitative statement that the calorimeter had retained a high level of air tightness (adequate for frozen food transport and storage [7]). If the mean wall temperature correction curve that had been determined when the calorimeter was new still applied, then the thermal transmittance would have been increased by $1.1 \%$

It should be noted that because of the nearly isothermal conditions at which tests of the calorimeter calibration device were performed, the calorimeter thermal transmittance heat gain made up a very small percentage of the total heat gain. At its greatest (Test No. 5) it was only $0.02 \%$ of the total. 
INTERIOR-EXTERIOR PRESSURE DIFFERENCE (Pa)

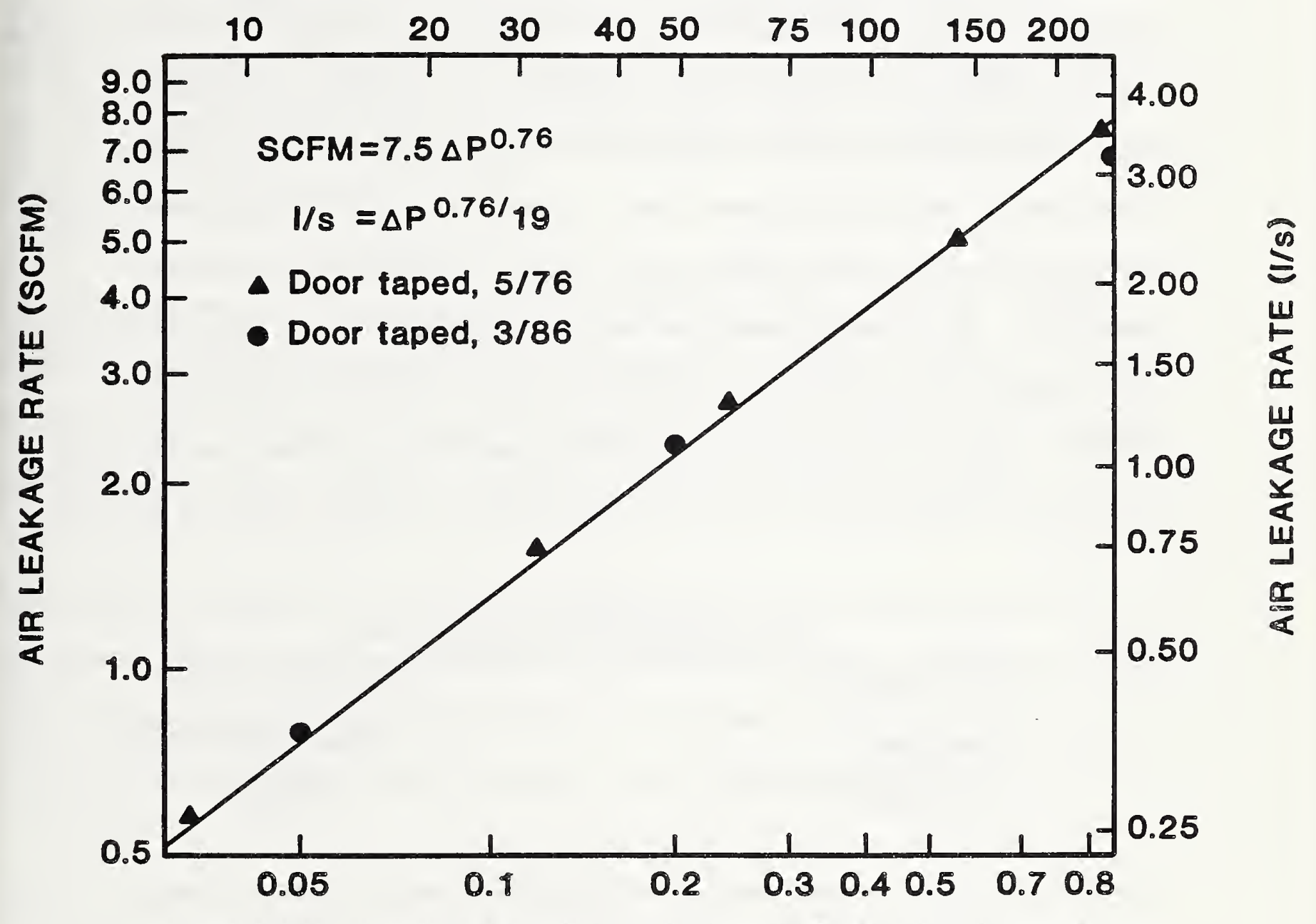
INTERIOR-EXTERIOR PRESSURE DIFFERENCE (In. W.G.) 


\section{Watt Hour Meter Calibrations and Line Loss}

A standard watt hour meter was used to calibrate the test watt hour meters used by NBS for measuring the base heater energy, variable heater circuit energy and 110 volt circuit energy supplied to the calorimeter during the KSU calorimeter calibration device tests. Some of these watt hour meter calibrations were performed duxing tests of the calorimeter calibration device and some afterward at power levels of particular interest. After the test meter calibrations had been completed the standard watt hour meter was calibrated at points near those used for the test meter calibrations by the Applied Electrical Measurements Group within the NBS Power and Energy Laboratory. The standard watt hour meter was calibrated at 8 points with an error ranging from $100.17 \%$ to $99.81 \%$ registration with an uncertainty of $\pm 0.065 \%$ or less. After these calibrations had been performed, calibration factors were calculated for the test watt hour meters as 1 isted in Table 3.

\section{Table 3}

Test Watthour Meter Calibrations (without line losses)

Watt Hour Meter

Base Heat

Variable Heat

110 Circuit
Correction Factor

$1.00640-(\mathrm{kW} * 0.00133)$

1.0080

1.0006

The test watt hour meters were not designed for installation of remote voltage taps. Therefore, after the tests of the KSU calorimeter calibration device had been completed, measurements were made of the voltage drop between the watt hour meters and the calorimeter at the test power levels. Since the current is the same through the load and its supply lines, the ratio between the power consumed by the load and that measured at the meter is equal to the ratio of the voltage measured at the load to that measured at the meter and 
also to the ratio of the load resistance to the total resistance (load+ lines).

A constant line loss correction of $1.46 \%$ was applied to the variable heat (i.e., \% loss $=$ Wh*0.0146). This degree of loss was measured with the variable heat manual ly set to $100 \%$ causing the SCR circuit to be inoperative. The load resistance connected to the variable heat circuit was not changed throughout this test series.

The base heat was varied by changing the load resistance. The line loss was measured at each fixed combination of load heaters possible as shown in figure 3. The linear regression shown by the dashed 1 ine in figure 3 resulted in the correction of $\%$ loss $=0.0757+\mathrm{kW}^{*} 0.092$ to be used for data analysis.

Power levels in the 110 volt $l$ ine were set primarily by variation in the amount of accessory equipment (circulating fan, psychrometer, humidifier). The line loss was measured at two power levels as shown in figure 4 and the linear correction factor resulting was: \% loss $=W * 0.0036$. 


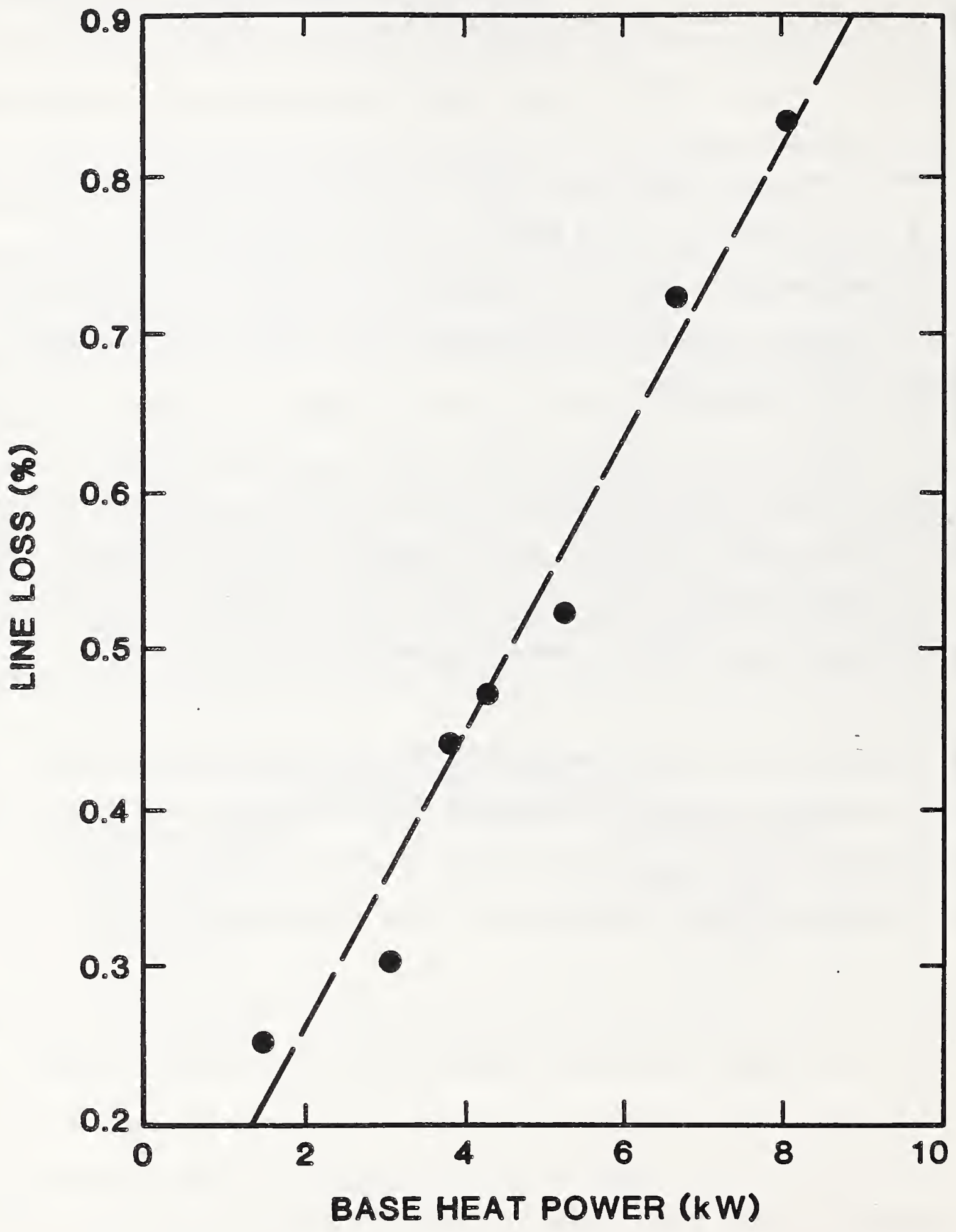

Figure 3: Base Heat Circuit Line Loss 


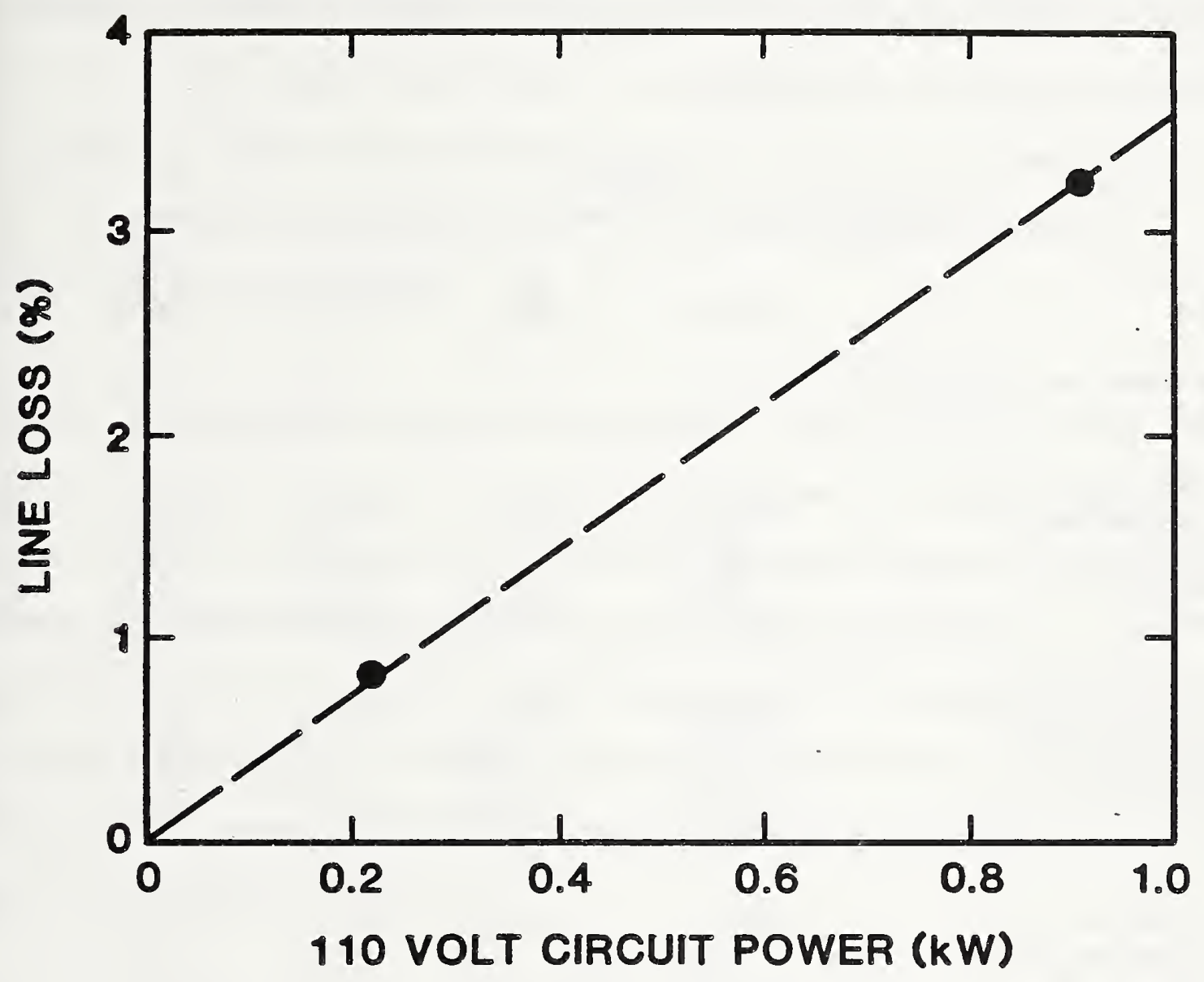

Figure 4: 110 Volt Circuit Line Loss 


\section{Data and Results}

The NBS calorimeter heat gain data for the five tests which were performed is summarized in Table 4. The total calorimeter heat gain listed in Table 4 is compared in Table 5 to the value measured by the KSU calorimeter calibration device.

Table 4

Summarized Calorimeter Heat Gain Data

\begin{tabular}{|c|c|c|c|c|c|}
\hline $\begin{array}{c}\text { Test No. } \\
\text { Date }\end{array}$ & $\frac{1}{2 / 11 / 86}$ & $\begin{array}{c}2 \\
2 / 12 / 86\end{array}$ & $\begin{array}{c}3 \\
2 / 13 / 86\end{array}$ & $\begin{array}{c}4 \\
2 / 13 / 86\end{array}$ & $\begin{array}{c}5 \\
2 / 14 / 86\end{array}$ \\
\hline $\begin{array}{l}\text { Calorimeter Wall Heat Gain } \\
(\text { UA } \triangle \mathrm{T}), W\end{array}$ & 8.9 & -1.1 & -12.8 & 3.1 & -8.4 \\
\hline Variable Heat: & & & & & \\
\hline $\begin{array}{l}\text { Meter Reading, W } \\
\text { Calibration, W } \\
\text { Line Loss, W } \\
\text { Total, W }\end{array}$ & $\begin{array}{r}1286.0 \\
10.3 \\
-18.9 \\
1277.4\end{array}$ & $\begin{array}{r}93.1 \\
0.7 \\
-1.4 \\
92.4\end{array}$ & $\begin{array}{r}811.4 \\
6.5 \\
-11.9 \\
806.0\end{array}$ & $\begin{array}{r}614.9 \\
4.9 \\
-9.0 \\
610.8\end{array}$ & $\begin{array}{r}901.8 \\
7.2 \\
-13.3 \\
895.7\end{array}$ \\
\hline $\begin{array}{l}110 \text { Volt Circuit: } \\
\text { Meter Reading, W } \\
\text { Calibration, W } \\
\text { Line Loss, W } \\
\text { Total, W }\end{array}$ & $\begin{array}{r}680.7 \\
0.5 \\
-16.8 \\
664.3\end{array}$ & $\begin{array}{r}865.3 \\
0.5 \\
-27.0 \\
838.8\end{array}$ & $\begin{array}{r}910.6 \\
0.5 \\
-29.9 \\
881.2\end{array}$ & $\begin{array}{r}988.9 \\
0.6 \\
-35.2 \\
954.3\end{array}$ & $\begin{array}{r}311.7 \\
0.2 \\
-3.6 \\
308.3\end{array}$ \\
\hline $\begin{array}{l}\text { Base Heat: } \\
\text { Meter Reading, W } \\
\text { Calibration, W } \\
\text { Line Loss, W } \\
\text { Total, W }\end{array}$ & $\begin{array}{r}3990.0 \\
4.4 \\
-17.6 \\
3976.8\end{array}$ & $\begin{array}{r}1488.2 \\
6.5 \\
-3.1 \\
1491.6\end{array}$ & $\begin{array}{r}6877.6 \\
-18.6 \\
-48.7 \\
6810.3\end{array}$ & $\begin{array}{r}5426.5 \\
-4.3 \\
-30.9 \\
5391.3\end{array}$ & $\begin{array}{r}2987.4 \\
7.2 \\
-10.5 \\
2984.1\end{array}$ \\
\hline $\begin{array}{l}\text { Total Calorimeter Heat } \\
\text { Gain, W }\end{array}$ & 5927.4 & 2421.7 & 8484.7 & 6959.5 & 4179.7 \\
\hline
\end{tabular}

Table 5

Comparison of Calorimeter Heat Gain as Measured by NBS and KSU

\begin{tabular}{lrrrrr}
$\begin{array}{l}\text { Test Number } \\
\text { Date }\end{array}$ & 1 & 2 & 3 & 4 & \multicolumn{1}{c}{5} \\
NBS Heat Gain, W & $2 / 11 / 86$ & $2 / 12 / 86$ & $2 / 13 / 86$ & $2 / 13 / 86$ & $2 / 14 / 86$ \\
KSU Heat Gain, W & 5927.4 & 2421.7 & 8484.7 & 6959.5 & 4179.7 \\
Ditference, \% & 5811.7 & 2495.4 & 8480.8 & 6989.8 & 4187.9 \\
& -2.0 & +3.0 & -0.05 & +0.4 & +0.2
\end{tabular}

The information presented in Table 5 is shown graphically in figure 5 . It can 
The information presented in Table 5 is shown graphically in figure 5. It can be seen that the per cent difference between the NBS and KSU measured heat gain does not show a consistent bias (plus or minus) and is not a function of the capacity level at which the tests were run. However, referring back to Table 5, it does appear that the per cent difference is a function of when the test was run. That is, tests performed on the first two days had a relatively high disagreement and those performed on the last three days showed exceptionally good agreement.

Humidity was maintained within the calorimeter during the first three tests. This was not done during the last two tests because of concern that the humidity might be responsible for the poor agreement that was being observed between NBS and KSU measured heat gain and because of the 1 imited time available for further testing. Condensate was not collected by KSU during the tirst test performed. Calorimeter humidity conditions, NBS measured humidity generation (moisture addition) rate, and KSU measured condensation col lection rate are summarized in Table 6 .

Table 6

Summarized Calorimeter Humidity and Condensate Data

$\begin{array}{lccc}\begin{array}{l}\text { Test Number } \\ \text { Date }\end{array} & 1 & 2 & 3 \\ & 2 / 11 / 86 & 2 / 12 / 86 & 2 / 13 / 86 \\ \text { Average Dry Bulb, }{ }^{\circ} \mathrm{F} & 80.7 & 81.6 & 82.1 \\ \text { Average Wet Bulb, }{ }^{\circ} \mathrm{F} & 66.5 & 69.1 & 68.4 \\ \text { Average Dew Point, }{ }^{\circ} \mathrm{F} & 58.8 & 62.9 & 61.4 \\ \text { Average Relative Humidity, \% } & 47.8 & 53.7 & 50.1 \\ \text { Humidity Generated by NBS, 1bs/hr } & 2.67 & 2.92 & 6.40 \\ \text { Condensate Collected by KSU, lbs/hr } & -- & 2.42 & 6.53 \\ \text { Difference, \% } & -- & -17.1 & +2.0\end{array}$




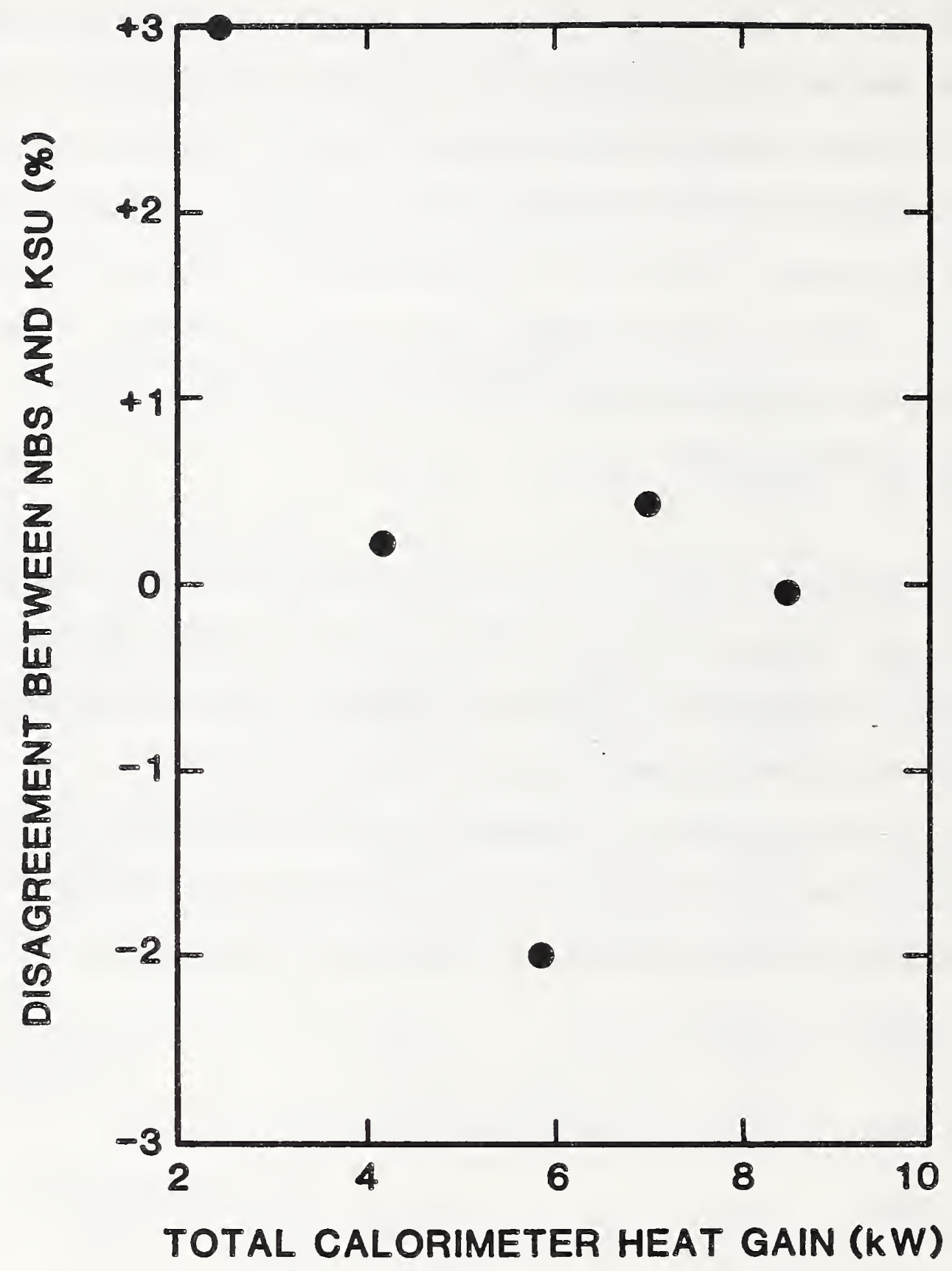

Figure 5: Comparison of Calorimeter Heat Gain as Measured by NBS and RSU 


\section{Discussion and Conclusions}

of the tive tests performed, the agreement was poor between the KSU and NBS measurements of total calorimeter heat gain for the first two tests, $2 \%$ and $3 \%$, respectively. A possible explanation for the disagreement on the first test was an inoperative damper in the air handler (due to a software error) which was corrected before performance of the second test.

For the final three tests, the agreement between the RSU and NBS measurements of the total calorimeter heat load was well within the program objective $( \pm 0.5$ per cent in measurement of total calorimeter load).

The agreement between the RSU and NBS measurements of the total calorimeter heat load did not appear to be a function of load, humidity, or to have a consistent bias. Because of the small number of tests performed and the questionable validity of the first two tests, statistical analysis of the test results would not be meaningful.

Two comparisons of latent capacity were made. One showed good agreement (2.0\%), the other unacceptable divergence $(-17.1 \%)$. The test with good agreement on latent capacity also showed good agreement on total capacity. The test showing poor agreement on latent capacity was also one of the first two tests which showed comparatively poor agreement on total capacity.

It would have been very desirable to have run several additional tests to resolve the discrepancies observed in the first two tests. These tests would have shown whether or not the discrepancies can be attributed to "start up" difficulties or due to true differences between the systems. 


\section{References}

1. "Method of Testing for Rating Room Air Conditioners and Packaged Terminal Air Conditioners," ASHRAE Standard 16-1983, (American Society of Heating, Refrigerating, and Aix Conditioning Engineers, Atlanta, Georgia 30329, 1986).

2. "ASBRAE Handbook of Fundamentals - 1985," Chapter 20, "Thermal Insulation and Water Vapor Retarders," (American Society of Heating, Refrigerating, and Air Conditioning Engineers, Atlanta, Georgia 30329, 1985).

3. Kramex, W.E. and Thompson, J.G.s "A Standard Device for Calibrating Calorimeter Test Rooms - Control System," ASHRAE Transactions, Vo1.92, Part IA, (American Society of Heating, Refrigerating, and Air Conditionnng Engineers, Atlanta, Georgia 30329, 1986)。

4. Thowe, M.E. $_{0}$ and Thompson, J.G., "A Standard Device for Calibrating Calorimeter Test Rooms - Operating System," ASHRAE Transactions, Vol. 92, Paxt IA, (Amexican Society of Heating, Refrigerating, and Air Conditioning Engiveers, Atlanta, Georgia 30329, 1986).

5. Beck, B.T., Jones, B.W., and Mianadoab, F.H., "A Standard Device for Cal ibrating Calorimeter Test Rooms o Prototype Heatmeter Device," ASHRAE Transactions, Vol。92, Part 1A, (American Society of Heating, Refrigerating, and Air Conditioning Engineers, Atlanta, Georgia 30329 , 1986).

6. Jones, B.W. and Beck, B.T., "A Standard Device for Calibrating Calorimeter Test Rooms - Accuracy Determination," ASHRAE Transactions, Vo1. 92, Part 1A, (American Society of Heating, Refrigerating, and Air Conditioning Engineers, Atlanta, Georgia 30329, 1986). 
7. Requirements for Thermal Van Containers (Refrigerated, Heated and Insulated)," ANSI MIT5.1.2M-1980, (American Society of Mechanical Engineers, New York, N.Y. 10017, 1980). 
NBS-114A (REV. 2-8C)

U.S. DEPT. OF COMM.

1. PUBLICATION OR

REPORT NO
NBSIR-86/3465

BIBLIOGRAPHIC DATA

SHEET (See instructions)

4. TITLE AND SUBTITLE

Evaluation of a Standard Device for Calibrating Calorimeter Test Rooms

\section{AUTHOR(S)}

William J. Mulroy

6. PERFORMING ORGANIZATION (If joint or other then NBS, see in structions)

MATIONAL BUREAU OF STANDARDS

DEPARTMENT OF COMMERCE

WASHINGTON, D.C. 20234

9. SPONSORING ORGANIZATION NAME AND COMPLETE ADDRESS (Street。City。 Stote, ZIP)

7. Contrac/ Grant No.

Office of Conservation and Renewable Energy

Department of Energy

Washington, D.C. 20585

\section{SUPPLEMENTARY NOTES}

\section{Doeument describes a computer program; SF-185. FIPS Sofeware Summary, is attached.}

11. ABSTRACT (A 200-word or less faczual summary of most significant informotion. If document includes a significant bibliogrophy or literature survey. mention it here)

A device for calibrating calorimeter test rooms was evaluated by installing it on a test room calorimeter of small, known thermal transmittance which contained electri heaters capable of providing varying metered heat loads. The calibration device wa evaluated only for its ability to measure heat load. The calorimeter instrumentati is described in detail. The calibration device is described primarily by reference

12. KEY WOROS (Six to twelve entries; olphabetical ordep; capitalize only proper names; and separate key words by semicolons air conditioning; calorimeters; room air conditioners; test methods; test rooms

13. AVAILABILITY

区्र Unlimired

$\square$ Fop Official Distribution. Do Not Release to NTIS

$\square$ Order From Superintendent of Documents, U.S. Government Printing Office, Washington, D.C. 20402.

[x Order From National Technical Information Service (NTIS), Springfield, VA. 2216I
14. NO. OF

PRINTED PAGE

26

15. Price

$\$ 11.95$ 